$10-2001$

\title{
Literary Evidence for Roman Arithmetic with Fractions
}

David W. Maher

John F. Makowski

Loyola University Chicago, jmakow1@luc.edu

Follow this and additional works at: https://ecommons.luc.edu/classicalstudies_facpubs

Part of the Ancient History, Greek and Roman through Late Antiquity Commons

\section{Recommended Citation}

Maher, DW, and Makowski, JF. "Literary evidence for Roman arithmetic with fractions" in Classical Philology 96(4), 2001. 376-399.

This Article is brought to you for free and open access by the Faculty Publications and Other Works by Department at Loyola eCommons. It has been accepted for inclusion in Classical Studies: Faculty Publications and Other Works by an authorized administrator of Loyola eCommons. For more information, please contact ecommons@luc.edu.

\section{(c) (i) $\ominus$}

This work is licensed under a Creative Commons Attribution-Noncommercial-No Derivative Works 3.0 License. (c) University of Chicago Press, 2001. 


\title{
LITERARY EVIDENCE FOR ROMAN ARITHMETIC WITH FRACTIONS
}

\author{
DAVID W. MAHER AND JOHN F. MAKOWSKI
}

$\mathrm{R}$

OMAN ARITHMETIC IS A PERENNIALLY TROUBLING subject for both classicists and mathematicians. Scholars universally comment on the difficulty posed by Roman alphabetical notation both in expressing simple figures and in doing written calculations. For example, Lloyd Motz and Jefferson Weaver with exasperation ask, "How . . can anyone do any arithmetic with DCCCLXXXVIII, the Roman equivalent of 888?," and Florian Cajori concludes that the Romans must have resorted to the abacus in order to multiply a number like 723 (DCCXXIII) by 364 (CCCLXIV). ${ }^{1}$ Yet our sources, literary and inscriptional, indicate that the Romans were capable of highly sophisticated calculations, and, of course, it is well recognized that they had great facility with the abacus and with finger reckoning. The arithmetic problems that appear in Latin literature have been treated in depth by only one author, Gottfried Friedlein (1866 and 1869). This is surprising because Latin literature provides a rich supply of material that deals with arithmetical problems and calculations. This paper will examine these materials in an attempt to determine, first, what the Romans actually did with their number system, and second, how the problems of arithmetic in classical literature were solved.

The reason generally advanced for the difficulty of Roman arithmetic has been the absence of "place value" in the Roman numeral system and the absence of the numerical symbol for zero. The theoretical basis of written computations was addressed by D. E. Smith in 1925 and later by French Anderson and by Michael Detlefsen. ${ }^{2}$ Anderson explains the mental processes by which numeral symbols, without place value and without a zero, may be used as a notation system for performing arithmetic computations. ${ }^{3}$ Anderson shows that the notation system provided the mental references, whether written or kept in memory, for keeping track of the operations

1. Motz and Weaver 1993, 29; Cajori 1907, 11, and 1928, 11. Other authors who have commented on the difficulties they perceive in doing basic arithmetic computation are Taisbak (1965), Menninger (1969), Strebe $(1971,13)$, Rotman $(1987,9-10)$, and Dilke $(1987,16)$.

The most significant studies, however, are the two studies of Friedlein (1866, 569-72, and 1869), and, of course, Hultsch's entry "Arithmetica" in RE (1895) is indispensable.

2. Smith 1925; Anderson 1956; Detlefson et al. 1976.

3. For the use of other notational systems see Anderson 1958; Tod 1979; Ifrah 1985; and also Keyser (1988), who provides a handy table of basic acrophonic Greek numerals.

[〔 2001 by The University of Chicago. All rights reserved] 0009-837X/01/9604-0003\$02.00 
performed by the person doing the computations. Detlefsen provides an explanation with an abundance of mathematical symbols. Whether or not Anderson and Detlefsen provide an accurate account of mental processes occurring two thousand years ago, they at least provide a theoretical basis for an examination of surviving texts that deal with arithmetic problems.

Little has been written analyzing the arithmetic computations that survive in Roman literature. Part of the reason for this may be the absence of a written record of simple, everyday computations. It may be assumed that arithmetic problems were from time to time written on a papyrus or a slate board or a wax-covered tablet, but, except for the problems that have survived in Latin literature, there is no surviving record of an arithmetic problem, such as a schoolboy's exercise or a merchant's calculation, having been written down on any of these materials. ${ }^{4}$ However, Latin literature discloses problems that could not have been handled by the abacus or by finger reckoning.

Before dealing with the instances of arithmetic in Latin literature, it will be helpful to review very briefly the role of the abacus and finger reckoning in ordinary Roman life, and also to review some general principles of a number system that does not employ place value, as we know it, in its written numbers.

The abacus, which originated in the Middle East as early as 2000 B.C.E., was commonly used by the Egyptians, the Greeks, and the Romans. (See appendix 1 for a list of references to the abacus in Latin literature.) The general form and function of the abacus remained unchanged from the Roman version to the newer version based on the swanpan (Chinese) or soroban (Japanese) reintroduced from the East. ${ }^{5}$ Anyone familiar with the operation of the abacus (in its Eastern or Western versions) will recognize that the abacus is a device that employs place value. ${ }^{6} \mathrm{~A}$ bead or counter in any column has a different value from that of the bead or counter (of identical appearance) in any other column. This is purely and simply place value, just as the so-called Hindu-Arabic system of numbers gives a different value to any digit (e.g., 1), depending on its location relative to other digits or to a decimal point.

The generally accepted accounts of Roman finger reckoning similarly recognize that the finger positions had place value. ${ }^{7}$ In showing any number on one or both hands, the Romans recognized a "base ten" number system, and started counting groups of tens, hundreds, or thousands by employing different fingers from those used for the integers one through nine. (See appendix 2 for a list of references to finger reckoning in Latin literature.)

4. For example, the accounts of the Pompeiian merchant Caecilius Jucundus, reproduced in CIL, volume 4, supplement 1 (K. Zangemeister, Tabulae ceratae Pompeis repertae, 1898), show no calculations whatever.

5. For the history of the abacus and its applications see Pullan 1968 and Moon 1971.

6. For an excellent discussion, complete with diagrams, sculptural evidence, and sample calculations, of how the Romans used the abacus, see Bonner 1977, 180-88. Also of interest are Menninger 1969, 312; Taisbak 1965; and Krenkel 1969.

7. On Roman finger reckoning see Turner 1951; Menninger 1969; Bonner 1977; Rieche 1986; and most recently, Williams and Williams 1995. 
In other respects, the Roman number system was clearly a base ten system. The Latin names for numbers go to ten and then use ten, twenty, thirty, and so on, as the starting point for the repetition of the names for one through nine. The Romans used shorthand notation for powers of ten, such as $((\mid))$ for ten thousand and $(((\mid)))$ for one hundred thousand, in a way that is weakly analogous to modern scientific notation, which uses superscripts for powers of ten. ${ }^{8}$ There were different symbols for one, five, ten, fifty, one hundred, five hundred, and one thousand, ${ }^{9}$ but no separate symbols, as such, for the digits two, three, four, six, seven, eight, nine, or for those digits in combination with the other basic symbols. The concept of zero as a number symbol and as a place holder in a place-value-oriented number system was unknown to the Romans. ${ }^{10}$

The use of Roman fractions in arithmetic presents far more complex problems. There is no known representation in Roman literature or inscriptions of a fraction expressed numerically as a numerator and denominator, and, obviously, there could be no representation of a fraction in decimal form. There are, however, a few verbal references to fractions with a numerator greater than one.

As is well known, the Romans had a fraction system not unlike those of other peoples in the ancient world. It was a "unitary" fraction system in which the basic fractions all had the numerator one. Appendix 3 is a table of the symbols employed in writing the fractions in common use. Like the Babylonians and the British of many centuries later, the Romans knew that twelve, rather than ten, is far better as a base for dividing things. In the predecimal days of British currency, twelve pence to the shilling and twenty shillings to the pound facilitated dividing the pound in three equal parts, a convenience that has been sacrificed to the modern fascination with decimal computation.

The Roman fractional system was derived from measures of weight and land. ${ }^{11}$ The fundamental fraction was one part in twelve; there was a separate symbol, $S$, for one-half, presumably selected because it is the initial of semis. The basic unit of weight was the uncia, twelve of which formed one $a s .{ }^{12}$ The basic unit of land area was the scripulum, ten feet by ten feet, which was $1 / 288$ of the area of the iugerum. As shown in appendix 3 , unitary duodecimal fractions from $1 / 12$ down to $1 / 288$ required only seven different

8. For a discussion of successive decade symbols in Etruscan numerals see Keyser 1988, esp. 533-34.

9. For the most recent research on the origins of the number symbols, see Keyser 1988, 529-46. Useful discussion is also found in de Vaux 1917 and Cajori 1919.

10. For the concept of zero in Greek mathematics, however, see Neugebauer (1969), who discusses the notion in Ptolemy's Almagest and in Byzantine palaeography.

There was limited use of place value in the so-called subtractive principle. It was the Roman convention to place symbols for larger numbers always towards the left. However, digits such as four, nine, forty, ninety, and nine hundred were commonly represented by IV, IX, XL, XC, and CM, respectively. It is not so well known that the same system was used to represent eight and eighty by IIX and XXC, respectively. Aside from religious consideration that led early Christians to avoid the use of IX as profaning the initials of IESOU XRISTOU, there appears to be no rhyme or reason to the use or non-use of this subtractive principle. A fascinating example is a single inscription that uses both LXXX and XXC for eighty, namely, CIL 1.2.638. For further discussion, see Neugebauer 1969, 4-5. On Christians and numbers, see Smith 1926.

11. For number terms in legal texts the standard source is Seckel 1907.

12. Volusius Maecianus, a teacher of Marcus Aurelius, wrote a treatise commonly called Assis distributio. See Hultsch [1864-66] 1971, 115-16. 
symbols. Also, it was easy to combine them so long as the written notations were based on a denominator of twelve, or one of its multiples up to 288 . The names for fractions thus included $1 / 3,1 / 4,2 / 3,3 / 4,5 / 6,5 / 12,7 / 12$, and unitary fractions down to $1 / 288$. There was no common name for $1 / 7,1 / 9,1 / 10$, or $1 / 11$. At some point in time, the Romans evidently realized that, starting with the basic fractions described above, they could approximate very closely to relationships that we describe in general fractions, that is, fractions with numerators that are any whole numbers as well as denominators that are any whole numbers. ${ }^{13}$ The Romans (with one or perhaps two exceptions described below) did not deal with general fractions such as five parts in seventeen, or 37 parts in 357 . They would approach these problems by starting with the nearest smaller fractional notation of the type shown in appendix 3 , and then adding on the twelve-based smaller fractions until a good approximation was reached. As will be shown below, they did extremely well at reaching good approximations.

The question of what the Romans actually did when they solved arithmetic problems is the subject of this paper. There is likely to be endless argument over what the Romans actually did when they used an abacus, or, as was more likely, moved pebbles (calculi) on lines drawn in the dust; there will be more arguments over what the Romans actually did when they employed the finger reckoning system. What is surprising, however, is the relatively limited attention paid to the harder questions of what the Romans did when faced with problems that could not be solved by the use of an abacus (in the forms used in ancient Rome) or by finger reckoning.

A review of the writings of Columella, Pliny the Elder, Frontinus, Victorius of Aquitaine, and, last but not least, Horace, will show that the Romans were not so handicapped in doing arithmetic as has generally been thought in modern times.

\section{REVIEW OF THE LITERARY EVIDENCE}

The writings of Columella provide a good starting point for consideration of the question of what the Romans did with numerals and fractions. In the De re rustica, Columella, like a number of other Latin authors, uses the term semis or semissis as a specification of a rate of interest. ${ }^{14}$ In context, it is clear that the Romans used these terms to express what in modern terminology works out to be a percent, or parts of a hundred. The semis, which would usually translate as "one-half " or "six-twelfths," was also used in the sense of the common rate of interest for one month on one hundred units. According to the clear sense of a passage in Columella, this rate would translate today as one-half of 1 percent per month. Thus, for twelve months, the rate of interest would in decimal notation be 6 percent, or .06 . Columella uses this concept in his argument for planting vineyards as an investment (Rust. 3.3.8-9):

13. It is interesting to note that the Egyptians long before the Romans had a system for denoting fractions; see Robins and Shute 1987, 19-35. See also Gillings 1972, esp. chap. 10, "Unit-Fraction Tables," 104-19, and Clagett 1955, esp. 14.

14. See the entries for semis and semissis in TLL and $O L D$. 
... fit tamen in assem consummatum pretium sestertiorum viginti novem milium. Huc accedunt semisses usurarum sestertia tria milia et quadringenti octoginta nummi bienni temporis. ... Fit in assem summa sortis et usurarum triginta duorum milium quadrigentorum octoginta nummorum. . . . eius summae ut in perpetuum praedictam usuram semissium dominus constituat, percipere debet in annos singulos mille nongentos quinquaginta sestertios nummos....

... still, the total price, reckoned to the last as, comes to 29,000 sesterces. In addition there is the interest at 6 percent per year, amounting to 3,480 sesterces for the two-year period. . . The sum total of principal and interest comes to 32,480 sesterces. . . . so that in order for the owner to realize the aforementioned 6 percent interest on that total as a perpetual annuity, he ought to take annually the 1,950 sesterces.

By modern calculations, Columella's first computation is exactly correct; six parts in a hundred of 29,000 for two years is 3,480 , and added to 29,000 it makes 32,480 . After this, Columella's figures do not correspond with modern calculations since six parts in a hundred of 32,480 is not 1,950 , but $1,948.8$.

There is no internal indication of how Columella arrived at his answer. One possible solution is that Columella derived the first of his answers by dividing 29,000 by one hundred and then multiplying the dividend by six, a straightforward exercise in Roman numerals, which would yield the desired result as a whole number. If he then went on to compute 6 percent of 32,480, he would, in Roman numerals, divide $\overline{X X X}$ MM CDLXXX by C, giving CCCXXIV and a remainder. Multiplying that by VI would give MCMXLIV. However, if the dividend were rounded up to CCCXXV (which would be logical since the remainder exceeds one-half), multiplying by VI would give MCML, the figure arrived at by Columella.

Another possible solution has been suggested that is far more complex but is intriguing because of the literary evidence that lends some support to it. There is the famous passage in Horace's Ars poetica (325-26):

Romani pueri longis rationibus assem

discunt in partes centum diducere.

Roman boys learn in long calculations how to divide into a hundred parts.

This can be interpreted as meaning that boys memorized tables of equivalents for parts in a hundred. ${ }^{15}$ Thus, Columella, in figuring six parts in a hundred of 29,000 for two years as 3,480 might have known, either from memory, or perhaps by consulting a table, that six parts of a hundred could be computed by using Roman fractions. As will be shown later, Frontinus, writing several decades after Columella, did in fact use Roman unitary fractions to express relationships between areas.

Friedlein (1866) discussed the passage quoted from Horace and worked out the equivalent for one part in a hundred as follows:

15. Dilke $(1987,50)$ translates partes centum as "tiny parts," arguing that the specific use of the word for one hundred has no meaning, but this flies in the face of the clear meaning of semisses as used by Columella and other authors for six parts per hundred per year. 


$$
\begin{aligned}
1 / 100=144 / 14,400=(100+44) / 14,400 & =1 / 144+44 / 14,400 \\
44 / 14,400=132 / 43,200 & =1 / 432+32 / 43,200 \\
32 / 43,200=128 / 172,800 & =1 / 1,728+28 / 172,800 \\
1 / 100=1 / 144+1 / 432+1 / 1,728= & =1 / 72(1 / 2+1 / 6+1 / 24)
\end{aligned}
$$

The remainder, 28/172,800, was neglected as not being large enough materially to affect the answer. Extending Friedlein's calculations, it follows that six parts in one hundred could be expressed in unitary fractions as:

$$
1 / 12(1 / 2+1 / 6+1 / 24)
$$

This modern form of arithmetical expression may be somewhat misleading. We would simplify this fraction into the form $17 / 288$, but there is no evidence that the Romans used fractions in this form. They might have multiplied by $1 / 288$ and then multiplied the resulting product by 17 (or vice versa), but, again, there is no evidence of this. If we assume that the Romans tended always to use unitary fractions in their computations, then it is possible to gain some insight into Columella's computations. Using Columella's problem, 29,000, multiplied first by $1 / 288$, with the product then multiplied by 17, provides an answer of MDCCXI S:. $\{2$ (expressed in Roman numerals), or $1,711+3 / 4+1 / 24+1 / 72$ (in modern notation), an answer that is far from Columella's.

A more productive approach is based on the use of a slightly different set of unitary fractions, namely:

$$
1 / 12[1 / 2+1 / 6+1 / 24+(1 / 3 \times 1 / 36)+1 / 288]
$$

and an assumption about the treatment of remainders. If a series of calculations is performed, in order, as described below, and if all remainders are neglected, Columella's answer can be obtained. Because remainders are neglected, only the calculations within the brackets are commutative. The first calculation must determine a product that becomes the multiplicand for the fractions in the brackets.

Perform the following steps:

1. The first step is to calculate $1 / 12$ of 29,000 :

$$
1 / 12(29,000)=2,416 \text { (plus remainder of } 8 \text {, which is neglected) }
$$

2. The second step is to multiply 2,416 by the fractions within the square brackets, neglecting the remainder in each computation of a product:

$$
\begin{array}{r}
1 / 2(2,416) \\
1 / 6(2,416) \\
1 / 24(2,416)
\end{array}
$$

$$
\begin{aligned}
& =1,208 \text { (exactly) } \\
& =402 \text { (plus remainder of } 16) \\
& =100 \text { (plus remainder of } 16)
\end{aligned}
$$

(The following computation is in two steps-multiplication of 2,416 by $1 / 36$ and then multiplication of the resulting product by $1 / 3$, with all remainders neglected.) 


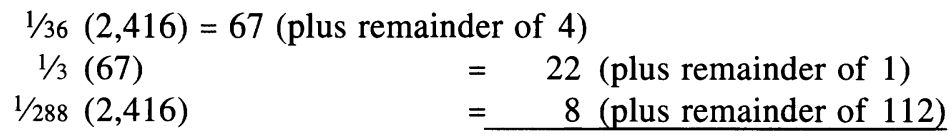

3. The final step is to sum the products calculated above:

Sum: 1,740 for one year, or 3,480 for two years.

The other problem is handled in the same way:

1. Calculate $1 / 12$ of 32,480 :

$1 / 12(32,480)=2,706$ (plus remainder of 8 , which is neglected)

2. Multiply 2,706 by the fractions within the square brackets, neglecting remainders:
$1 / 2(2,706)$
$1 / 6(2,706)$
$=1,353$ (exactly)
$1 / 24(2,706)$
$=451$ (exactly)
$=112$ (plus remainder of 18$)$

(two steps)

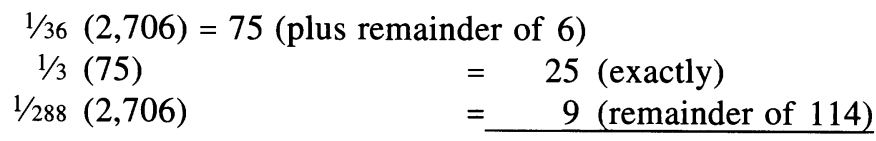

3. Sum the products:
Sum:
1,950

Whether there is any other set of unitary fractions that would produce the correct result is an interesting question. ${ }^{16}$

Just as our best source for understanding Roman finger counting comes from the early Middle Ages, ${ }^{17}$ our best source for a Roman multiplication table, or table of equivalents, also comes from a postclassical source.

Victorius of Aquitaine, who wrote in the fifth century C.E., provided an extensive multiplication table that gives an idea of what must have been common computations. The arrangement of the table is different from that of modern ones; there are ninety-eight vertical columns, of which every

16. The problem of finding one solution, from an enormous number of possibilities, that is the best fit is sometimes referred to as the "backpack problem." In this case, the fact that the solution described above works for two separate problems is some evidence that it may be the best solution. The authors are indebted to Paul T. Keyser (1986 and 1988) for a thoroughly modern approach to finding additional solutions. Keyser is now advisory programmer at the T. J. Watson Research Center of IBM in Hawthorne, N.Y. With modern computational resources, Keyser wrote several programs in an attempt to find better and more elegant solutions to this problem. He was able to show that there are thousands of solutions if fractions with numerators larger than one are used. There are also many solutions using unitary fractions, but many of these do not produce the desired result if the assumptions above are employed (the first set of calculations being noncommutative and remainders neglected). All possible shorter fractions were checked and none gave the correct results, so any fraction used by Columella must have had at least five terms.

17. On this point see Menninger 1969, 312. 
second one is an unchanging guide column, a list of numbers starting with one thousand, descending by hundreds to one hundred, then descending by tens to ten, then by ones to one, and then the fractions down to $1 / 144$. The first, third, and every alternate column contain the products obtained by multiplying the number in the guide column by the whole numbers, starting with two and ending with fifty.

A partial representation is given below: ${ }^{18}$

\begin{tabular}{|c|c|c|c|c|c|}
\hline $\begin{array}{l}\text { Product } \\
\text { column: } \\
\text { twice the } \\
\text { number in } \\
\text { the guide } \\
\text { column }\end{array}$ & $\begin{array}{l}\text { Guide } \\
\text { column }\end{array}$ & $\begin{array}{c}\text { Product } \\
\text { column: } \\
\text { three times } \\
\text { the number } \\
\text { in the guide } \\
\text { column }\end{array}$ & $\begin{array}{l}\text { Guide } \\
\text { column }\end{array}$ & $\begin{array}{c}\text { Product } \\
\text { column: } \\
\text { fifty times } \\
\text { the number } \\
\text { in the guide } \\
\text { column }\end{array}$ & $\begin{array}{l}\text { Guide } \\
\text { column }\end{array}$ \\
\hline$\overline{\mathrm{II}}$ & $\overline{\mathrm{I}}$ & $\overline{\text { III }}$ & $\overline{\mathrm{I}}$ & $\overline{\mathrm{L}}$ & $\overline{\mathrm{I}}$ \\
\hline ĪDCCC & DCCCC & IIDCC & DCCCC & $\overline{\mathrm{XLV}}$ & DCCCC \\
\hline $\mathrm{CC}$ & $\mathrm{C}$ & $\mathrm{CCC}$ & $\mathrm{C}$ & $\overline{\mathrm{V}}$ & $\mathrm{C}$ \\
\hline II & I & III & I & $\mathrm{L}$ & I \\
\hline IS:: & S::: & IIS:. & S::: & XLVS::. & S::: \\
\hline
\end{tabular}

Even though this is apparently the earliest surviving multiplication table for Roman whole numerals and fractions, the evidence of the computations of Columella and others points to the conclusion that similar tables existed earlier or were created as the occasion required. ${ }^{19}$ It is interesting to note that the multiplication table provides the products of whole numbers from one to fifty and all the fractions, but no products of fractions multiplied by each other. $^{20}$

Pliny the Elder is an author whose arithmetic is of interest primarily because it presents several puzzles to the modern reader. Although Pliny was not adept at mathematics, as will be seen, he was the first author (of a surviving work) to show a conception of fractions more general than the traditional Roman system. This can be seen in his account of the dimensions of the earth in the Naturalis historia (6.38):

Nunc ipsarum partium magnitudo conparabitur, utcumque difficultatem adferet auctorum diversitas; aptissime tamen spectabitur ad longitudinem latitudine addita. Est ergo ad hoc praescriptum Europae magnitudo ... longitudo $|\overline{\mathrm{LXXXI}}| \overline{\mathrm{XLVIII}}$. Africae

18. The representation is drawn from Friedlein 1871, 443-63.

19. The use of multiplication tables is not by any means an invention of the Romans. There is an extensive review of multiplication tables, reciprocal tables, and metrological lists and tables from the Old Babylonian period (c. 2000 B.C.E.) in Nemet-Nejat 1995. The author (241) states that multiplication and reciprocal tables "were used by students at the elementary level of scribal education and probably outside
the schools as well."

20. It is interesting to note that, according to Nemet-Nejat $(1995,245)$, division in Babylonian arithmetic is "rarely performed," making knowledge of reciprocals essential. A reciprocal table (e.g., products of numbers multiplied by $1 / 3,1 / 4,1 / 5$, etc.) would give the same results as a division table. It is conceivable that this approach to division filtered down in antiquity to the Romans and influenced their apparent use of unitary fractions in lieu of general fractions. See also Archibald 1994. 
(ut media ex omni varietate prodentium sumatur computatio) efficit longitudo $\mid \overline{\mathrm{XXX}}$ $\overline{\text { VII }} \mid \overline{X C V I I I}$ latitudo, qua colitur, nusquam $\overline{\mathrm{DCCL}}$ excedit. Sed quoniam in Cyrenaica eius parte $\overline{\mathrm{DCCCCX}}$ eam fecit Agrippa, deserta eius ad Garamantas usque, qua noscebantur, complectens, universa mensura quae veniet in comparationem $|\overline{\mathrm{XLVII}}| \overline{\mathrm{VIII}}$ efficit. Asiae longitudo in confesso est $|\overline{\mathbf{L X}}| \overline{\mathrm{III}} \mathrm{DCCL}$, latitudo sane computetur ab Aethiopico mari Alexandriam iuxta Nilum sitam, ut per Meroen et Syenen mensura currat, $|\overline{X V I I I}| \overline{\mathrm{LXXV}}$. Apparet ergo Europam paulo minus dimidia Asiae parte maiorem esse quam Asiam, eandem altero tanto et sexta parte Africae ampliorem quam Africam. Quod si misceantur omnes summae, liquido patebit Europam totius terrae tertiam esse partem et octavam paulo amplius, Asiam vero quartam et quartam decimam, Africam autem quintam et insuper sexagesimam.

We will now compare the dimensions of particular parts of the earth, however great the difficulty that will arise from the discrepancy of the accounts given by the authors; nevertheless the matter will be most suitably presented by giving the breadth in addition to the length. The following, then, is the formula for the area of Europe ... length 8,148 miles. As for Africa-to take the average of all the various accounts given of its dimensions - its length works out to 3,798 miles, and the breadth of the inhabited portions nowhere exceeds 750 miles; but as Agrippa made it 910 miles at the Cyrenaic part of the country, by including the African desert as far as the country of the Garamantes, the extent then known, the entire length that will come into the calculation amounts to 4,708 miles. The length of Asia is admittedly 6,375 miles, and the breadth should properly be calculated from the Ethiopic Sea to Alexandria on the Nile, making the measurement run through Meroe and Syene, which gives 1,875 miles. It is consequently clear that Europe is a little less than one and a half times the size of Asia, and two and one-sixth times the width of Africa. Combining all these figures together, it will be clearly manifest that Europe is a little more than $1 / 3+1 / 8$, Asia $1 / 4+1 / 14$, and Africa $1 / 5+$ $1 / 60$, of the whole earth. ${ }^{21}$

21. The translation is that of Rackham (1942). Vitruvius refers to the concept of one-eighth as octava pars, not as sescuncia (the normal term for the fraction), and uses it in a computation of the circumference of the earth, which meant the perimeter of a flat disk on which the Mediterranean formed a belt across the center. In De architectura 1.6.9, he gives the standard classical figure for the circumference of the earth, 252,000 stadia, multiplies by 125 , for the number of paces, and then divides by eight: "Si autem animadverterint orbis terrae circuitionem ... esse inventam ducentorum quinquaginta duum milium stadium, quae fiunt passus trecenties et decies quinquies centena milia, huius autem octava pars . . . est triciens nongenta triginta septem milia et passus quingenti...." ("If they note, however, that the earth's circumference ... has been found to be 252,000 stades, which gives $31,500,000$ paces, while the eighth part of this . . . is $3,937,500$ paces. ...").

Somewhat before Vitruvius, Varro used Roman fractions in his De re rustica 1.10: “ . . iugerum, quod quadratos duos actus habeat. actus quadratus, qui et latus est pedes CXX et longus totidem. ... Iugeri pars minima dicitur scripulum, id est decem pedes et longitudine et latitudine quadratum. ... habet iugerum scripula CCLXXXVIII, quantum as antiquos noster ante bellum Punicum pendebat. Bina iugera quod a Romulo primum divisa dicebantur viritim, quae heredem sequerentur, heredium appellarunt. Haec postea centum centuria. Centuria est quadrata, in omnes quattuor partes ut habeat latera longa pedum MMCD." (". . . a iugerum, which has two square actus. A square actus, which is 120 square feet. . . The smallest part of a iugerum is called a scripulum, that is, ten feet squared in width and in length . . . a iugerum has 288 scripula, which is how much our ancient as weighed before the Punic war. Two iugera, because they were first allotted to each man by Romulus, were called a haeredium because they could be willed to an heir. Later a hundred of these constituted a centuria. A centuria is squared so that sides have a length of 2400 feet.") This description of the various measures of area shows how their relationships were expressed through the use of Roman fractional notation. By going through the arithmetic in Varro's figures, it can be seen that the square actus, 120 feet by 120 feet, has an area of 14,400 square feet, and the iugerum thus has 28,800 square feet. Since the scripulum is 10 feet by $10 \mathrm{feet}$, then its area is $1 / 288$ of the iugerum. The later square centuria referred to by Varro, equaling 200 iugera, works out correctly to be a square with sides of 2,400 feet (area - 5,760,000 square feet). See Tilly 1973, 49 . 
Among the difficulties in interpreting this passage are textual variations in several places. In the second sentence, longitudo is a conjectural reading commonly put before the figure, on the assumption that a copyist omitted the figure for the breadth of Europe and then the word longitudo. Most of the figures have variant readings, but the ones given are the most logical in view of the mathematical relationships. Editorial opinion is also divided on the meaning of the first sentence; it appears to say that length and breadth are added to determine the size of a figure. This, if true, is a sad comment on Pliny's mathematical knowledge, and some editors have assumed a different meaning: "Scholars have taken the words to mean, "by adding the breadth to the length,' and have charged Pliny with thinking that this would give the area!" 22 The most convincing argument for taking the obvious interpretation is that the measurements given for Africa, and the total size at the end, are simply the sum of length and breadth. ${ }^{23}$

In spite of the flaws in Pliny's method of computing area, his use of fractions marked an important advance in Roman mathematics. The difficulties involved in being bound too tightly to a duodecimal fractional system were apparent in Columella's work. If he could have used $1 / 16$ or $1 / 17$ as an equivalent for six parts in a hundred, he would have saved considerable time. Pliny used fractions of this sort, although he (or his scribes) were unable to express them with figures; for instance, $1 / 14$ is referred to as quartam decimam, and $1 / 60$ as sexagesimam. He did not take the final step of converting $1 / 3+$ $1 / 8$ to $11 / 24$, or $1 / 4+1 / 14$ to $9 / 28$, or $1 / 5+1 / 60$ to $13 / 60$. From the relationships expressed by these fractions, some light is shed on the textual difficulties. Since the total "size" of Africa is given as 4,708 miles, it can be assumed that the "size" of Asia is the sum of its length and breadth, or $6,888.75$ miles. The former is $1 / 5$ plus $1 / 60$ of the world total, and the latter, $1 / 4$ plus $1 / 14$. The world total comes out in the first case to be 21,729 miles, and in the second, 21,431. Although this is not ideal accuracy, it is perhaps as good as might be expected from Pliny. These figures are also the best that can be found by using various combinations of the textual variations in the lengths and breadths.

Two other relationships can be checked, and these are also somewhat inaccurate. Europe's "size" is supposed to be paulo minus ("a little less") than $1 \frac{1}{2}$ times that of Asia and 21/6 times that of Africa. Paulo minus is inexact, but by computing $2 \frac{1}{6}$ times the "size" of Africa, the "size" of Europe must be close to 10,200 miles, and therefore the breadth, to Pliny, must have been originally about 1,500 miles (i.e., $10,200-8,714$ ).

22. So Rackham $(1942,492)$.

23. It seems quite likely that Quintilian was referring to this mistake of Pliny in his Institutio oratoria (1.10.39-40): "Nam quis non ita proponenti credat? 'Quorum locorum extremae lineae eandem mensuram colligunt, eorum spatium quoque, quod iis lineis continentur, par sit necesse est.' At id falsum est. Nam plurimum refert, cuius sit formae ille circuitus; reprehensique a geometris sunt historici, qui magnitudinem insularem satis significari navigationis ambitu crediderunt." "Who is there who would not accept the following proposition? 'When lines bounding two figures are equal in length, the areas contained within those lines are equal.' But this is false, for everything depends on the shape of the figure formed by these lines, and historians have been taken to task by geometricans for believing the time taken to circumnavigate an island to be a sufficient indication of its size.") 
The peak of extant Roman accomplishments in arithmetic is the $D e$ aquae ductu urbis Romae of Frontinus. Commissioned by the emperor Nerva, Frontinus' work was finished around 98 C.E. and was a survey of the state of the Roman water supply. In his explanations of some of the technical details, Frontinus included a summary of the sizes of water pipes used, and the units of measure involved. ${ }^{24} \mathrm{He}$ was not under Pliny's delusion about area, as the following passage shows (2.65):

... inveni altitudinem aquae pedum quinque, latitudinem pedis unius dodrantis: fiunt areae pedes octo dodrans. . . . ${ }^{25}$

I found a depth of water of 5 feet, and a width of $13 / 4$ feet, making an area of $83 / 4$ feet. . . . ${ }^{26}$

The most significant computations in Frontinus' work are contained in 1.24:

Est autem digitus, ut convenit, sextadecima pars pedis, uncia duodecima. Quemadmodum autem inter unciam et digitum diversitas, ita et ipsius digiti simplex observatio non est. Alius vocatur quadratus, alius rotundus. Quadratus tribus quartisdecumis suis rotundo maior, rotundus tribus undecumis suis quadrato minor est, scilicet quia anguli deteruntur.

Now the digit, by common understanding, is $1 / 16$ part of a foot; the inch $1 / 12$ part. But precisely as there is a difference between the inch and the digit, just so the standard of the digit itself is not uniform. One is called square; another round. The square digit is larger than the round digit by $3 / 14$ of its own size, while the round is smaller than the square by $3 / 11$ of its size, obviously because the corners are cut off.

This passage concerns the units of measure used in water pipes. A digitus is one-sixteenth of a foot, and an uncia, one-twelfth of a foot (i.e., in modern terms, one inch), but there are two kinds of area measured by a digitus: one, a circle with one digitus the diameter, and the other, a square with a side of one digitus. In Frontinus' expression of the relative sizes of these areas, he used, as far as we know, a truly general type of fraction for the first time in Roman literature. He stated that the area of a square with a side of one digitus was larger than the area of a circle with a diameter of one digitus by $3 / 14$ of its own size, and the circle was smaller in area than the square by $3 / 11$ of its own size. Put in more general terms, this describes the relation of the areas of the largest circle that can be inscribed in any given square. This can be expressed mathematically by:

$a^{2}-3 a^{2} / 14=\pi a^{2} / 4$, where $a$ is the side of the square and diameter of the circle, one digitus, and $\pi a^{2} / 4+3 \pi a^{2} / 44=a^{2}$; solving these equations for $\pi$ :

24. The most important studies on the technology of Roman waterworks and on Frontinus are those of Landels (1978, esp. 53-57); Pace (1983); Kretzschmer (1983, 57-72); Rodgers (1986); and Hodge (1992).

25. Citations of Frontinus are taken from C. Kunderewicz's Teubner edition of 1973.

26. Unless otherwise noted, translations of Frontinus are those of Bennett (1956). 


$$
\begin{aligned}
& 1-3 / 14=\pi / 4 \\
& 28-6=7 \pi \\
& \pi=22 / 7
\end{aligned}
$$

and

$$
\begin{aligned}
& \pi / 4+3 \pi / 44=1 \\
& 11 \pi+3 \pi=44 \\
& 14 \pi=44 \\
& \pi=22 / 7 .
\end{aligned}
$$

This shows conclusively that Frontinus used $22 / 7$ for $\pi$, although it is not clear exactly how he performed his computations. ${ }^{27}$ Wherever Frontinus used the general concept of fractions, the surviving manuscripts show the fractions in words, and this makes it impossible to see how he actually worked with them. Presumably, the problem had to be written down, since the Roman abacus and all known methods of finger reckoning are not capable of expressing general fractions.

After this innovation in fractions in one section of his work, Frontinus returned to the traditional means of expression in another passage (1.26). The arithmetic here is more complicated, because four pipe sizes are being compared (modulus is the word used for pipe size). Frontinus describes the digitus rotundus, a round pipe with a diameter of one digitus; the digitus quadratus, a round pipe whose cross-sectional area is equal to that of a square with a side of one digitus; the quinaria, a round pipe with a diameter of five fourths of a linear digitus; and the uncia, a round pipe with a diameter of one uncia.

At 1.26, Frontinus gives the relationships of the diameters and crosssectional areas (i.e., capacity) of the quinaria compared to the uncia:

Unciae ergo modulus habet diametri digitum unum et trientem digiti; capit plus, quam quinaria, quinariae octava, hoc est sescuncia quinariae et scripulis tribus et bese scripuli.

So the inch pipe has a diameter of $1 \frac{1}{3}$ digits. It holds more than $1 \frac{1}{8}$ quinariae, that is, one and one-half twelfths of a quinaria plus $3 / 288$ plus $2 / 3$ of $1 / 288$.

The first expression shows that a pipe with a diameter of one uncia equals one with a diameter of one and one-third digiti. This is correct, as can be seen:

27. By contrast, Vitruvius, working approximately 150 years earlier, thought that $\pi$ was $3 \frac{1}{8}$. In his $D e$ architectura (10.9.1) he described an ancient predecessor of the odometer (a revolving wheel that measures distances traveled) and gave the dimensions of the wheel; he said that the diameter was four feet, and the circumference twelve and a half: "Rotae, quae erunt in raeda, sint latae per medium diametrum pedum quaternum, ut, cum finitum locum habeat in se rota ab eoque incipiat progrediens in solo viae facere versationem, perveniendo ad eam finitionem, a qua coeperit versari, certum modum spatii habeat peractum pedes XIIS." This gives for $\pi$ the value $31 \frac{1}{8}$. For a description and diagram of an ancient odometer, see Singer 1923, 300, and for a more recent study connecting Vitruvius to experiments of Leonardo da Vinci, see Sleeswyk 1981. More general discussion is found in Fields 1994. 
1 uncia $=1 / 12$ foot

1 digitus $=1 / 16$ foot

$$
(1+1 / 3) \times(1 / 16)=1 / 12 \text {. }
$$

The capacity of the uncia pipe is then given as more than $11 / 8$ of a quinaria pipe, to be exact, $1+1 / 8+3 / 288+(2 / 3 \times 1 / 288)$. How Frontinus selected these fractions is a mystery, but, whatever technique he employed, the representation is almost exactly correct. In modern arithmetical terms we would express the relationship as follows:

capacity of quinaria is one-half of the diameter of the digitus multiplied by $5 / 4$, giving the radius, which is then squared and multiplied by $\pi$;

capacity of uncia is one-half of the diameter of the digitus multiplied by $4 / 3$, giving the radius, which is then squared and multiplied by $\pi$.

The relationship is determined by dividing the square of the radius of the uncia by the square of the radius of the quinaria:

$4 / 9$ divided by $25 / 64=256 / 225=131 / 225$

$131 / 225$ would be expressed in decimal terms as $1.1377777+$.

The fractions in Frontinus' expression can be expressed in decimal form as 1.137732 , which is astonishingly accurate - to less than four parts in one hundred thousand. How Frontinus arrived at these particular fractions is not known, but we can show how close his fractional representation comes to our expression:

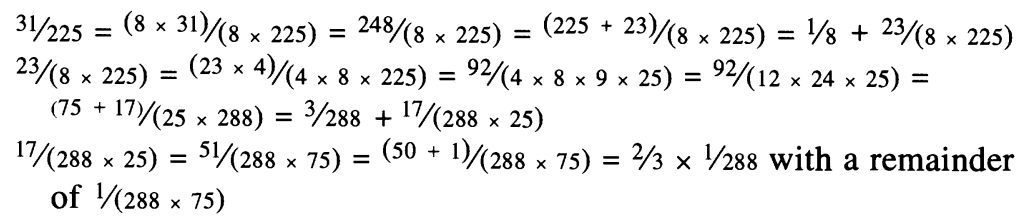

The remainder could be further approximated, in Roman notation, as the product of $1 / 288$ times $1 / 72$, but it may be that Roman multiplication did not extend this far.

The next type of pipe dealt with is the digitus quadratus, the round pipe with a cross-sectional area equal to that of a square with a side of one digitus. It is compared to the quinaria and described as follows (26.5):

Digitus quadratus in rotundum redactus habet diametri digitum unum et digiti sescunciam sextulam; capit quinariae dextantem.

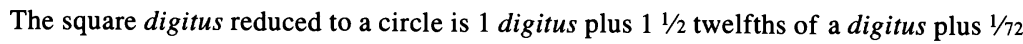
in diameter; its capacity is $10 / 12$ of a quinaria.

According to Frontinus, its diameter is $1+1 / 8+1 / 72$ linear digiti, and its cross-sectional area is ten-twelfths that of a quinaria. This is reasonably accurate; using modern calculations and expressing $\pi$ as 3.14159 , we would say that the diameter of the digitus quadratus is 1.1284 . Using $\pi$ with a 
value of $22 / 7$, we would express the diameter as 1.1281 . Frontinus' approximation works out to 1.1389 . By modern calculations, the cross-sectional area of the digitus quadratus is .8149 of the quinaria (or .8145 , using $22 / 7$ for $\pi$ ); according to Frontinus, it is .8333 of the quinaria.

Finally, Frontinus compares the cross-sectional area of the digitus rotun$d u s$ to that of the quinaria (26.6):

Digitus rotundus habet diametri digitum unum; capit quinariae septuncem semunciam
sextulam.

The circular digit is 1 digit in diameter; its capacity is $7 / 12$ plus $1 / 2$ twelfth plus $1 / 72$ of a quinaria.

The digitus rotundus, with a diameter of one digitus, has, according to Frontinus, a capacity of $7 / 12+1 / 24+1 / 72$ of a quinaria. By modern calculations, we would say that the relationship is $.6400+$ (or .64 , using $22 / 7$ for $\pi$ ); Frontinus' calculation is .6389 , expressed as a decimal.

For Frontinus to have arrived at these figures must have required considerable computing, but there is again no indication of how they were obtained. Frontinus may have had a multiplication table similar to the one we know from Victorius of Aquitaine. This seems a safe assumption since knowledge of multiplication itself implies the ability to create a multiplication table. If Frontinus understood the concept of general fractions, and was able to divide a numerator of any whole number by a denominator of any whole number, he might have performed his calculations either on an abacus, or by using finger reckoning. Even though he expressed the result of the comparison of the two types of digitus in 1.24 by using general fractions, namely, $3 / 11$ and $3 / 14$, he may have felt that going beyond these relatively small numbers would not be meaningful to his intended audience and therefore reverted to expressions in the fractional notation then in common usage.

It is interesting to note that the accuracy of the first comparison is significantly better than that of the latter two. Frontinus could have come closer in the latter two comparisons by extending the sum of the fractions. In the first comparison, his use of the product of $2 / 3$ times $1 / 288$ represents a discrimination that we would express as .0023 , or something more than two parts in one thousand. Since he knew $2 / 3$ of $1 / 288$, presumably he could also have used $1 / 3$ of $1 / 288$, which permits a discrimination of one part in one thousand. However, Frontinus' representations of the latter two comparisons are off by as much as two parts in one hundred.

Speculating on what Frontinus actually did with these numbers may suggest a general approach to the question of Roman concepts of fractions. In the first case, the comparison of the uncia and the quinaria, the division of one general fraction by another results in the answer $1+31 / 225$. The general fraction $31 / 225$ is equal to $124 / 900$, which is slightly less than $14 / 100$. In the second case, the comparison of the digitus quadratus and the quinaria, the comparison of the cross-sectional areas is made by dividing the square of the radius of the digitus quadratus, namely $7 / 22$ (assuming $\pi$ is $22 / 7$ ), by the square of the radius of the quinaria, namely $25 / 64$, giving the result $448 / 550$. 
This general fraction is equal to $896 / 1,100$, which is slightly more than $81 / 100$. In the third case, the square of the radius of the digitus rotundus is $1 / 4$; this is divided by the square of the radius of the quinaria, giving the result $16 / 25$, which is exactly equal to $64 / 100$. Perhaps this reflects the computing thought process of Frontinus - a computation using general fractions, which are converted to the nearest equivalent in parts of one hundred, and then perhaps a conversion to the Roman fractional notation that would be familiar to his readers.

Friedlein $(1866,570)$ believed that the Romans had tables of equivalents for parts in one hundred. This belief is supported by the passage from Horace quoted above and by a commonsense view of the way Romans used their symbols for numbers. The concept of parts in one hundred as a return on investment may well have originated in a counting of whole numbers of measures of grain or other produce. If a farmer has one hundred containers of grain and is obligated to pay six parts in one hundred, it is easy to count out six units. The problem of expressing this in writing arises when the Roman attempts to express this using the only numerical symbols available at the time, namely, the unitary fraction symbols. Frontinus was able to perform his mathematical computations to compare cross-sectional areas by using general fractions, but when he wanted to give expression to his results, he used the symbols meaningful to a general audience.

Friedlein says that one part in one hundred is equivalent to $1 / 72(1 / 2+1 / 6$ $+1 / 24)$; the alternative suggestion of this paper is that $1 / 72[1 / 2+1 / 6+1 / 24+$ $(1 / 3 \times 1 / 36)+1 / 288]$ gives a result that supports the computations of Columella. Without a table of equivalents that was actually used by the Romans, it is impossible to speculate how these equivalents might have been used to produce the results of Frontinus. The multiplication table of Victorius of Aquitaine shows that the concept of multiplying Roman fractions by whole numbers was understood in his time. Considering the works of Frontinus and Columella, there is no reason to think that this kind of multiplication table was unknown to Romans of an earlier era.

Approaching this problem from the vantage point of two millennia later is not easy, but if one thinks in terms of the unitary fractions used by the Romans, a theory of the basis for a table of equivalents may be constructed. The uncia $(1 / 12)$ was the fundamental Roman "subunit." The names of certain multiples of the uncia, i.e., deunx $(11 / 12)$, decunx $(10 / 12)$, nonuncium $(9 / 12)$, septunx $(7 / 12)$, quincunx $(5 / 12)$, and teruncius $(4 / 12)$ show that the uncia was the starting point. Similarly, the name sescuncia for $1 / 8$ is one and one-half of one-twelfth. Fractions smaller than an uncia used by the Romans were the product of the uncia and the other fundamental fractions, $1 / 2,1 / 3,1 / 4$ and $1 / 6$. Thus, there were names and symbols for $1 / 24,1 / 36,1 / 48,1 / 72$, but not for $1 / 96$.

Unfortunately, there is no surviving literary evidence that offers a basis for an underlying theory of how the Romans harmonized their use of a whole-number system based on tens, hundreds, and thousands (and halves of these numbers) with parts of one hundred and duodecimal fractions. From a practical standpoint, Frontinus was not handicapped by the Roman notation system. He obtained results that were adequate for his purposes, 
and the achievements of Roman architecture are ample evidence of the success of the Romans in practical mathematics.

\section{CONCLUSION}

In summo apud illos honore geometria fuit, itaque nihil mathematicis illustrius: at nos metiendi ratiocinandique utilitate huius artis terminavimus modum.

For them geometry held the supreme honor, and so nothing was more honored than their mathematicians, but we have limited this art to its usefulness for measuring and reckoning.

So writes Cicero in the Tusculan Disputations (1.2.5). The illos refers to the Greeks, and Cicero's phrase sums up quite neatly the distinction between Greek and Roman mathematics. ${ }^{28}$ By comparison with the heights attained by the Greeks, the Romans have always come off second best, but this is no reason for overlooking their solid achievements in the practical use of numbers. If it is assumed to be impossible to perform written computations with Roman numerals or indeed with any non-place-value system, it is partly understandable why Roman arithmetic has been so ignored. The works by Anderson and later writers on computations with Roman numerals have changed the situation. There is also the view that Roman arithmetic and nearly all mathematics were used only by tradespeople and taught only to their sons, and for this reason was held in contempt by the higher levels of Roman society. But this is not consistent with the amount of arithmetical knowledge exhibited by various authors here discussed, and by a passage from Quintilian's Institutio oratoria (1.10.35):

\footnotetext{
Nam cum sit geometria divisa in numeros atque formas, numerorum quidem notitia non oratori modo, sed cuicunque saltem primis litteris erudito necessaria est. In causis vero vel frequentissime versari solet; in quibus actor, non dico, si circa summas trepidat, sed si digitorum saltem incerto aut indecoro gestu a computatione dissentit, iudicatur indoctus. ${ }^{29}$

Geometry has two divisions; one is concerned with numbers, the other with figures. Now knowledge of the former is a necessity not merely to the orator, but to any one who has had even an elementary education. Such knowledge is frequently required in actual cases, in which a speaker is regarded as deficient in education, I will not say if he hesitates in making a calculation, but even if he contradicts the calculations which he states in words by making an uncertain or inappropriate gesture with his fingers.
}

28. A modern echo of Cicero's evaluation is Tropfke 1930, 159: "Das lange Festhalten an diesem höchst ungeschickten Systeme, in dem schwierige Rechnungen römischer Ingenieure und Feldmesser nur noch schwieriger und unübersichtlicher wurden, ist ein Zeugnis für die geringe wissenschaftlich-mathematische Mitarbeit der Römer." For another view see Carruccio's chapter "Mathematics in the Roman World" (1964, 124-49).

29. Cicero in his speech against Verres (2.3.49) demonstrates his facility with calculations: "Professio est agri Leontini ad iugerum $\overline{\mathrm{XXX}}$; haec sunt ad tritici medimnum $\overline{\mathrm{XC}}$, id est mod. $\overline{\mathrm{DXXXX}}$; deductis tritici

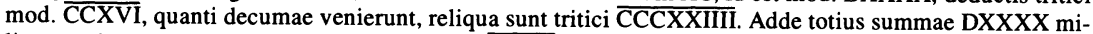
lium mod. tres quinquagesimas; fit tritici mod. XXXIICCCC (ab omnibus enim ternae praeterea quinquagesimae exigebantur) sunt haec iam ad CCCLX mod. tritici." Hultsch $(1895,1111)$, in modern notation, puts the four calculations thus: "Die Exempel a) $90000 \times 6=540000$, b) $540000-216000=324000$, c) 540 $000 \times 3 / 50=32400$ d) $324000+32400=360000$ nahezu rechnet Cicero in Verr. III 116 aus." 
There is no completely satisfactory proof that any particular computational system is the one actually used by the Romans, and probably there never will be any certainty, unless some merchant's or schoolchild's wax tablet is found with calculations on it. Anderson's method of addition, subtraction, multiplication, and division undoubtedly gives insight into the Roman conception of arithmetic. Anyone who works with Roman numerals for several months (e.g., the authors of an article on this subject) can see that the only way to handle Roman numerals is individually, or in groups of like figures, and not according to the Hindu-Arabic conception. In other words, LXX must be treated as $L$ and $X$ and $X$, not as 7 and 0 .

The Roman educational system certainly included the study of arithmetic. Horace's Ars poetica (325-30) contains a humorous vignette of a boy's lesson in solving arithmetic problems:

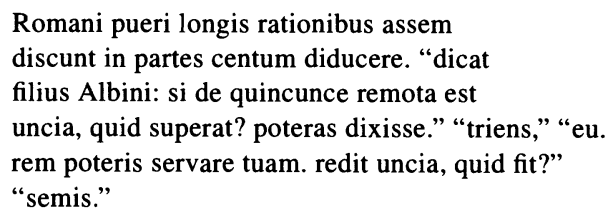

Roman boys learn in long calculations how to divide into a hundred parts. "Suppose Albinus's son says: if one-twelfth is taken from five-twelfths, what is left? You might have answered by now." "One-third." "Well done. You'll be able to manage your money. Now add a twelfth; what happens?" "One-half."

This passage, besides contrasting the Greeks' idealism about learning with Roman avarice, indicates the facility of schoolboys in handling fractions, as taught to them by the litteratores, generally, the first regular teachers a Roman boy had. ${ }^{30}$ This was the stage when the use of the abacus was taught (cf. Horace), and probably finger reckoning. ${ }^{31}$ Other sources confirm that memorization was very important and that the use of multiplication tables was common. The issue of numeracy occurs at least twice in Petronius. ${ }^{32}$ In the Satyrica, Hermeros, one of Trimalchio's freedmen guests, boasts of his ability to divide weights and money by a hundred (58.7):

Non didici geometrias, critica et alogas nenias (?); sed lapidarias litteras scio, partes centum dico ad aes, ad pondus, ad nummum.

I didn't learn geometry, criticism, and silly nonsense(?); but I know my capital letters; I recite percentages of a hundred in copper, in weights, in coins.

30. For a full commentary on the passage, see Brink 1971 ad loc. See also Bonner $(1977,183)$, who points out that the use of small coins would have greatly facilitated the calculation of fragments and says further that the system would have been used in apportioning an inheritance, which would have been treated like an as.

31. See Murison 1925, 232-33.

32. See Bonner 1977, 183. For an interesting argument about how numerate Petronius' characters are, see Horsfall 1989, 194-209, esp. 203-4 and Russell 1989, 210-25. Both the Horace and Petronius passages are well discussed by Hultsch 1889, 335-43. 
In similar fashion Echion (46.3) says that his little catamite can divide by four. ${ }^{33}$ It is clear that a person who used numbers at all would soon learn the table up to ten, if no further.

The literary evidence for the Romans' facility with arithmetic finds abundant corroboration in the evidence from inscriptions. For example, ILS 7753, a sepulchral inscription, tells of a twenty-year-old boy who could divide by 300 partes, that is, he could calculate an annual interest rate of 4 percent. ${ }^{34}$ Roman surveyors certainly used fractions, as evidenced by $I L S 8344$, which refers to agro iugeribus duobus dextante semuncia, that is, $27 / 8$ iugera $(2+$ $10 / 12+1 / 24)$. An interesting inscription of the Arval Brotherhood, ILS 5049, makes extensive use of fractions, albeit with a slight error, in commemorating the lengths of theater rows assigned to the group.

If the ordinary well-educated Roman was familiar with the abacus, the parts of a hundred, and sums of unciae, this still does not explain the methods by which writers like Frontinus got their results. The De aquis urbis Romae is unique among extant works in its use of Roman numerals, but other construction engineers must have known something about this. The most likely explanation is that Frontinus used an abacus for multiplication and division, along with a wax tablet to write down some computations.

Although Cicero's phrase is enough to show that the Romans were not deeply interested in mathematics, it should not be taken to mean also that they ignored or did not use it. ${ }^{35}$ Roman numerals are unwieldy in certain aspects, namely, high numbers and fractions, but the entire system is still flexible enough to permit the solution of any problem in arithmetic.

Any educated Roman must have been able to do arithmetical problems as well or nearly as well as any educated person today. ${ }^{36}$

\section{Chicago \\ Loyola University Chicago}

\section{Appendix 1. Passages from Latin Works Containing REFERENCES TO THE ABACUS}

\section{Cicero}

Quid? Tu, inquam, soles cum rationem a dispensatore accipis, si aera singula probasti summam, quae ex his confecta sit, non probare? (Philosoph. Frag. 5.59)

33. Not all little Roman boys were as enthusiastic about doing figures as Horace's schoolboy or Echion's cicaro. St. Augustine tells us in his Confessions (1.13) how much he detested the singsong of unum et unum duo, duo et duo quattuor.

34. For a discussion of Roman calculation of interest rates, see Marquardt [1884] 1975, 58-64.

35. Cicero himself was certainly sophisticated enough in using fractions to calculate interest (Att. 4.15.7): "Fenus ex triente Idibus Quinctilibus factum erat bessibus."

36. The authors wish to thank Professor Mason Hammond and Mr. Livio Stecchini of Harvard University and Professor Joseph Warren Dauben, editor of Historia Mathematica. A special note of thanks to Mr. Paul T. Keyser of the IBM T. J. Watson Research Center for corrections and invaluable suggestions. 


\section{Historia Augusta (Capitolinus)}

Puer litteris elementariis et calculo imbutus. . . (Pertinax 1.4)

\section{Horace}

Laevo suspensi loculos tabulamque lacerto

(Sat. 1.6.74)

\section{Juvenal}

Ponatur calculus, adsint

cum tabula pueri ...

$$
\text { (Sat. 9.40-41) }
$$

Adeo nulla uncia nobis

est eboris, nec tessellae, nec calculus ex hac materia.

(Sat. 11.131-33)

\section{Lucilius}

Hoc est ratio? perversa aera, summa est subducta improbe

(886 ed. Marx)

\section{Martial}

Coponem laniumque balneumque, tonsorem tabulamque calculosque

$$
\text { (3.48-49) }
$$

\section{Persius}

nec qui abaco numeros et secto in pulvere metas scit risisse vafer

(Sat. 1.131-32)

\section{Appendix 2. Passages from Latin Works Containing REFERENCES TO FINGER RECKONING}

\section{Ambrose}

... ambobus in digitis usurarum repetitur saepius calculatio. (De Tobia 7.25)

\section{Augustine}

Omnium vero de hac re calculantium digitos resolvit ... (De civ. D. 18.53)

Nonaginta enim et novem in sinistra numerantur; unum adde, ad dexteram transitur. (Serm. 125.1)

Other references in St. Augustine's works: In Evang. Iohan. 122.7-8; Serm. 158.14, 175.1, 248.3 and 5, 249.3, 250.3, 251.5-7, 252.8-11, 270.7; and Ennarationes in Psalmos, 49.9, 150.1. 


\section{Boethius}

See In Porphy. Comm. 5A-D (Migne, PL 64, pp. 147-50).

\section{Cassianus}

Centenarius enim numerus de sinistra transfertur ad dextram ... (Conl. 24.26.7)

\section{Cassiodorus}

Sexagenarius enim numerus pertinet ad continentes et viduas, quod digitorum ipsorum mutua designat infixio. (Comm. in Psalmum LX)

ut merito hunc numerum obtinuisse videatur, qui speciem desiderabilis coronae digitorum dexterae manus inflexione designat. (Comm. in Psalmum C)

\section{Cicero}

Hoc quid intersit, si tuos digitos novi, certe habes subductum. (Att. 5.21.13)

\section{Firmicus}

... vides ut primos discentes computos digitos tarda agitatione deflectant ... (Mathesis 1.4.13)

\section{Macrobius}

Annos ergo coeuntium mitti in digitos exemplo Platonis nobis suffragante non convenit. (Sat. 1.1.6)

Inde et simulacrum eius plerumque fingitur manu dextera trecentorum et sinistra sexaginta et quinque numerum tenens ad demonstrandam anni dimensionem, quae praecipua est solis potestas. (Sat. 1.9.10)

Complicatus enim senarium numerum digitus iste demonstrat, qui omnifariam plenus perfectus atque divinus est. Causasque cur plenus sit hic numerus ille multis adseruit, ego nunc ut praesentibus fabulis minus aptas relinquo. Haec sunt quae in Aegypta divinarum omnium disciplinarum compote cur anulus huic digito magis inseratur agnovi. (Sat. 7.13.10)

Quisquis in digitos mittit, inveniet. (In Somn. 2.11.17)

\section{Martianus Capella}

... in digitos calculumque distribuit. (De nupt. Phil. 2.102)

Quae mox ingressa septingentos decem septem numeros complicatis in eos digitis Iovem salutabunda subrexit. (De nupt. Phil. 7.729)

Mihi vero solus numerus approbatur, qui digitis coercetur . . (De nupt. Phil. 7.746)

\section{Ovid}

seu quia tot digiti, per quos numerare solemus

... sollicitis supputat articulis.

(Pont. 2.3.18) 


\section{Pacianus}

Calculare denique si potes catholicos greges, et duc in digitos nostrae plebis examina. (Epist. ad Syn. tertia 3.25)

\section{Plautus}

quaere: ego hinc abscessero abs te huc interim. illuc sis vide, quem ad modum adstitit severo fronte curans, cogitans.

Pectus digitis pultat: cor credo evocaturust foras; ecce avortit: nixus laevo in femine habet laevam manum, dextera digitis rationem conputat, feriens femur dexterum. ita vehementer icit: quod agat aegre suppetit. concrepuit digitis: laborat; crebro conmutat status. eccere autem capite nutat: non placet quod repperit. quidquid est, incoctum non expromet, bene coctum dabit.

(Mil. 200-208)

... tot quot digiti tibi sunt in manu.

(Stich. 706)

\section{Pliny the Elder}

... qui pacis bellique argumento colitur digitis ita figuratis ut CCCLV dierum nota (aut per significationem anni temporis) et aevi esse deum indicent. (HN 34.16.33)

\section{Pliny the Younger}

. . . agitat digitos, computat . . (Ep. 2.20.3)

\section{Quintilian}

Nam gestum poculum poscentis aut verbera minantis aut numerum quingentorum flexo pollice efficientis, quae sunt a quibusdam scriptoribus notata, ne in rusticis quidem vidi. (Inst. 11.3.117)

\section{Seneca the Younger}

Numerare docet me et avaritiae commodat digitos potius quam doceat nihil ad rem pertinere istas conputationes ... (Ep. 88.10)

\section{Sidonius Apollinaris}

... Chrysippus digitis propter numerorum indicia constrictis ... (Epist. 9, Lib. 9.14)

\section{Suetonius}

... voce digitisque numeraret ... (Claud. 21$)$

\section{Tertullian}

... Multis instrumentis cum digitorum supputariis gesticulis adsidendum est ... (Apol. 19.5) 


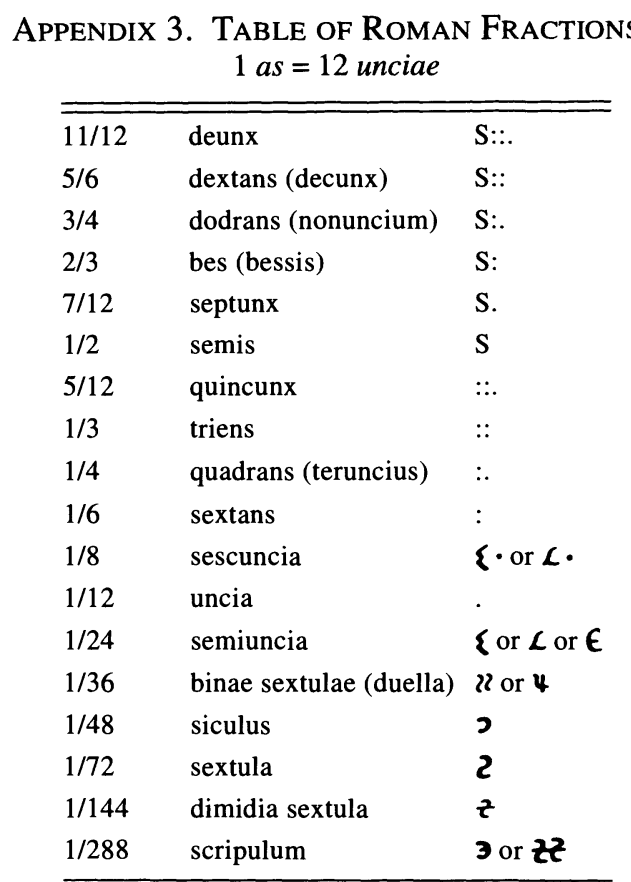

* Source: A. Bouché-Leclercq, Manuel des institutions romaines (Paris, 1886), 567.

\section{LITERATURE CITED}

Anderson, W. F. 1956. Arithmetical Computations in Roman Numerals. CP 51:145-50.

$\rightarrow$. 1958. Arithmetic Procedure in Minoan Linear A and in Minoan-Greek Linear B. AJA 72:363-68.

Archibald, R. 1994. Babylonian Mathematics with Special Reference to Recent Discoveries. In From Five Fingers to Infinity, ed. F. J. Swetz, 113-23. Chicago.

Bennett, C. E. 1956. Frontinus: The "Stratagems" and the "Aqueducts of Rome." Cambridge, Mass.

Bonner, S. 1977. Education in Ancient Rome. Berkeley.

Brink, C. O. 1971. Horace on Poetry: The "Ars Poetica." Cambridge.

Cajori, F. 1907. A History of Elementary Mathematics. New York.

$\longrightarrow \rightarrow$ 1919. The Controversy on the Origin of Our Numerals. Scientific Monthly 9:458-64. 1928. A History of Mathematical Notations I. LaSalle, Ill.

Carruccio, E. 1964. Mathematics and Logic in History and in Contemporary Thought. Trans. I. Quigly. Chicago.

Clagett, M. 1955. Greek Science in Antiquity. New York.

$\rightarrow$ Detlefsen, M., D. K. Erlandson, J. C. Heaton, and C. M. Young. 1976. Computation with Roman Numerals. Archive for History of Exact Sciences 15:141-48.

Dilke, O. A. W. 1987. Mathematics and Measurement. Reading the Past, vol. 2. Berkeley. 
Fields, M. 1994. Practical Mathematics of Roman Times. In From Five Fingers to Infinity, ed. F. J. Swetz, 200-205. Chicago.

Friedlein, G. 1866. Ủber das elementare Rechnen bei den Römern. Jahrbuch für klassische Philologie 93:569-72. 1869. Die Zahlzeichen und das elementare Rechnen der Griechen und Römer. Erlangen.

1871. Victorii Calculus. Bolletino di bibliographia e di storia 4:443-63.

Gillings, R. J. 1972. Mathematics in the Time of the Pharaohs. Cambridge, Mass.

Hodge, A. Trevor. 1992. Roman Aqueducts and Water Supply. London.

Horsfall, N. 1989. "The Uses of Literacy" and the Cena Trimalchionis: II. G\&R 36:194-209.

Hultsch, F. 1889. Ein Beitrag zur Kentniss des Volkstümlichen Rechnens bei den Römern.

Neue Jahrbücher für Philologie und Paedagogik 2:335-43. 1895. Arithmetica. RE 2:1066-1116.

. [1864-66] 1971. Metrologicorum Scriptorum Reliquiae. Reprint, Stuttgart.

Ifrah, G. 1985. From One to Zero: A Universal History of Numbers. Trans. L. Blair. New York.

$\rightarrow$ Keyser, P. 1986. Errors of Calculation in Herodotus. CJ 81:230-42.

$\rightarrow$. 1988. The Origin of the Latin Numerals 1 to 1000. AJA 92:529-46.

Krenkel, W. 1969. Das Rechnen mit römischen Ziffern. Das Altertum 15:252-56.

Kretzschmer, F. 1983. Bilddokumente römischer Technik. Dusseldorf.

Landels, J. G. 1978. Engineering in the Ancient World. Berkeley.

Marquardt, J. [1884] 1975. Römische Staatsverwaltung. Reprint, New York.

Menninger, K. 1969. Number Symbols and Number Words. Trans. P. Broneer. Cambridge, Mass.

Moon, P. 1971. The Abacus. New York.

Motz, L., and J. H. Weaver. 1993. The Story of Mathematics. New York.

Murison, W. 1925. Education. In Companion to Latin Studies ${ }^{3}$, ed. J. E. Sandys, 232-33. Cambridge.

$\rightarrow$ Nemet-Nejat, K. R. 1995. Systems for Learning Mathematics in Mesopotamian Scribal Schools. Journal of Near Eastern Studies 54:241-60.

Neugebauer, O. 1969. The Exact Sciences in Antiquity. New York.

Pace, P. 1983. Gli acquedotti di Roma e il "De aquaeductu" di Frontino. Rome.

Pullan, J. M. 1968. The History of the Abacus. London.

Rackham, H. 1942. Pliny: "Natural History." Vol. 2. Cambridge, Mass.

Rieche, A. 1986. Computatio Romana: Fingerzählen auf provinzialrömishcen Reliefs. BJ 186: 165-192.

Robins, G., and C. Shute. 1987. The Rhind Mathematical Papyrus: An Ancient Egyptian Text. London.

$\rightarrow$ Rodgers, R. H. 1986. Copia Aquarum: Frontinus's Measurements and the Perspective of Capacity. TAPA 116:353-60.

Rotman, B. 1987. Signifying Nothing: The Semiotics of Zero. New York.

Russell, D. A. 1989. Arts and Sciences in Ancient Education. G\&R 36:210-25.

Seckel, G. 1907. Heumanns Handlexicon zu den Quellen des römischen Rechts. Jena.

Singer, C. 1923. Science. In The Legacy of Rome, ed. C. Bailey, 300-324. Oxford.

$\rightarrow$ Sleeswyk, A. W. 1981. Vitruvius' Odometer. Scientific American, October, 188-200.

Smith, D. E. 1925. History of Mathematics. Boston. 40:69-78.

1926. The Roman Numerals, Second Part: Other Problems of Their History. Scientia

Strebe, D. D. 1971. Elements of Modern Arithmetic. Chicago.

Taisbak, C. M. 1965. Roman Numerals and the Abacus. C\&M 26:147-60.

Tilly, B. 1973. Varro the Farmer. London. 
Tod, M. N. 1979. Ancient Greek Numerical Systems. Chicago.

Tropfke, J. 1930. Geschichte der Elementar-Mathematik I. Berlin.

$\rightarrow$ Turner, J. H. 1951. Roman Elementary Mathematics: The Operations. CJ 47:106-108.

Vaux, C. de. 1917. Sur l'origine des chiffres. Scientia 21:273-82.

$\rightarrow$ Williams, B. P., and R. S. Williams. 1995. Finger Numbers in the Greco-Roman World and the Early Middle Ages. Isis 86:587-608. 